\title{
Frank Lloyd Wright: Separating The Man From The Myth
}

\author{
Maryam Siddiqui *, Chaitali Ahuja ** \\ DOI: 10.29322/IJSRP.11.08.2021.p11618 \\ http://dx.doi.org/10.29322/IJSRP.11.08.2021.p11618
}

\begin{abstract}
A comprehensive idea of a pioneer's life can only be established by the parallel understanding and criticism of multiple texts and forms of writing, including biographies, autobiographies and academic texts. When assessing an architect's life, their evolution of philosophy and design methods also demand to be studied through an analysis of individual works in a chronological order. Spaced even if at gaps of a few years, their buildings present a unique glimpse into the mind of the creator and often add more meaning to the readings they are coupled with. This paper aims to study the life and works of Frank Lloyd Wright in light of the various readings that surround him, with an aim to separate the man from the myth. The result is a clearer picture of the similarities and differences between the various texts and perceptions about Frank Lloyd Wright.
\end{abstract}

Index Terms- Frank Lloyd Wright, Priarie Style Architecture, Architect, Perception, Architecture

\section{INTRODUCTION}

$\mathrm{T}$ There have been many forerunners in the world of architecture, but only a few names stand out so prominently that even the layman recognizes them. Throughout history, there have been people who have completely transformed the built world; who stepped into the field of architecture as individuals but over time became movements. The nineteenth and twentieth centuries saw dramatic shifts in the tones of architecture, and a name whose contributions can never be overstated is Frank Lloyd Wright. Credited as being the creator of Prairie Style architecture, his buildings focussed on highlighting their surroundings and were inspired by the natural world. Known to be the most revered architect of America, he truly mastered Organic Architecture and designed around a thousand structures, out of which over five hundred were constructed (Lubow 2009). However, multiple readings on the life of Wright present multiple images of him. Thus, a comprehensive idea can only be achieved when the parallel writings are read together and analysed comprehensively.

\section{LITERATURE REVIEWED}

The primary arguments have been made from the following texts: Wright's autobiography titled 'An Autobiography,' his biography by Brendan Gill titled 'Many Masks: A Life of Frank Lloyd Wright', and the academic text by Thomas S. Hines titled 'The Search for Frank Lloyd Wright, History, Biography, Autobiography.' Other scholarly articles and biographies,

This publication is licensed under Creative Commons Attribution CC BY.

http://dx.doi.org/10.29322/IJSRP.11.08.2021.p11618 including those by Ingrid Steffenson and Ayn Rand are used as supplementary material to support the main arguments.

\section{BACKGROUND}

A significant understanding of Wright's character can be obtained from his autobiography, but not only would it be a biased perception, it would also be self-contradicting. Many attempts have been made to study his life and works, but they differ significantly and often present contrasting images. Frank Lloyd Wright's story begins in different years for different sources. According to Gill's text, even though Wright mentions in his autobiography that the year of his birth was 1869 , various official documents and records of his birth state his date of birth to be the 8th June of 1867 (Gill 1987). It is evident from his own as well as others' records that he had always been much closer to his mother than his father, and she, Anna Lloyd Jones Wright, has been presented in the autobiography in a glorifying light. Her passion was education, and she had been a teacher before her marriage to Frank's father, William Cary Wright. In Wright's autobiography, he mentions, 'Education was Sister Anna's passion even while very young. All this family was imbued with the idea of education as salvation' (Wright 1977 p.9). Even before he was born, Wright mentions, his mother wanted him to be an architect. An expectant Anna had no doubts that she was going to have a boy, and even hung on the walls of what was to be the child's room, ten flat-oak framed 'full-page wood engravings of the old English cathedrals from "Old England", a pictorial periodical to which the father had subscribed' (Wright 1977 p.11). As mentioned in the autobiography, 'Before he was born, she said she intended him to be an architect' (Wright 1977 p.11). However, this anecdote exposes the face of Wright that has been the cause of many controversies. According to the biography by Brandan Gill, the mother had few reasons, if any, to have these ambitions for her unborn child. Architecture was not considered a noble profession if even considered one during the late 1860s. The houses of the time were mostly made by carpenters, and the few who called themselves "architects" were neither actually architects but mere contractors, nor renowned enough to have been heard of by Sister Anna in the suburbs. The first school of architecture in the United States was opened by the name of Massachusetts Institute of Technology a year after Wright was born, with a total of only four students. As for the framed engravings of English cathedrals that are said to have adorned the walls of Frank's childhood room, Frank's mother, a devout Unitarian, would not have agreed with such grandeur-covered houses of worship. Thus, Gill argues in Many Masks, the mother's prenatal aspirations may very well be an imposition of Frank's imagination. The credibility of his 
autobiography is thus called to question even before the story reaches his birth. (Gill 1987).

\section{COMPARATIVE ANALYSIS}

It is this contradiction to reality, at times coupled with exaggeration, that has earned the visionary and revolutionary architect the titles 'manipulator' and 'hypnotic.' Other factors that reduce the trustworthiness of the autobiography as a source of information include the changed years of birth of Frank's parents and the age of his grandfather at the time of his death. In Wright's biography, Gill points out that three years of birth exist for Anna; the first being 1842-it is the one she used to tell others and the one that exists in most of Frank's biographies, the second is 1839- the one that exists on her records, and the third was 1837- two years later than the actual year which was also used by Wright in his autobiography. Though she may have changed it from 1839 to 1842 for the conventional desire to appear younger than she was, it seems peculiar for Wright to make his mother appear older than she is in his autobiography. Wright also increases his father's age by five years and calls him William Russell Cary Wright, even though the father did not have Russell in his name (Gill 1987). The autobiography suggests Wright's father was born in Hartford, Connecticut, even though he was born in Westfield, Massachusetts in 1825. William's father, Reverend David Wright, lived to be ninety-three years of age, but his grandson, Gill continues to state, increases his age at death to ninety-nine. The jumbling up of dates, very probably due only to inattention or faults in memory, also tells about a characteristic trait of Wright that stayed with him his entire life- that of changing facts as he pleased. The parallel study of texts thus reveals a trait very central to Wright's personality that might have gone unnoticed without an external pointing out of the inconsistencies in the dates and ages in Wright's own narration of the story of his life.

However, a change in the reader's outlook while studying the autobiography can also open him up to a new perception of Wright. It needs to be studied not for precise re-enactments of the past and an exact learning of dates, but for understanding the poetry of his life and the depth and complexity of his mind. Thomas S. Hines, in his article The Search for Frank Lloyd Wright: History, Biography, Autobiography, states that he was helped reach this appreciation by an article titled "Psychological Reality and Historical Actuality" by Erik Erikson. "An Autobiography exemplified the former. Most critical scholars have rightly sought the latter without sufficiently acknowledging the larger truth that the best history and biography comprise a subtle, critical, and complex blending of the two" (Hines, 1995, p. 469). It needs to be analysed not as precise source of history but as a work of fiction. Hines goes on to mention Hayden White's observations that historians only look for things that happened or physically existed at certain times during history, that can be assigned a time and a place as per their observation or perceiving. However, he argues, to "imaginative" writers such as poets and playwrights, imagined and invented things also matter in addition to the aforementioned (Hines 1995). Wright seems to embrace this inconsistency. According to Willaim Cronon, "Intent on proving the greatness of his soul from a very early age, Wright cherished his inconsistencies as if they were among his most beloved creations. The extraordinary talent that enabled him to produce such an astonishing array of architectural forms was matched by an equally extraordinary ability to revel in the polarities of his own soul no matter how incompatible they seemed" (Cronon, 1994, pg. $8)$.

The imagery with which Wright begins his life story provides an early peek into the way his mind worked. As he talks about his childhood self in third person, presumably working on the lines of Louis Sullivan and Henry Adams, he talks about the nature and his surroundings in great detail. The opening words show his interest in nature and his fascination with it. 'A light blanket of snow fresh-fallen over sloping fields, gleaming in the morning sun...Pattern to the eye of the sun, as the sun spread delicate network of more pattern in blue shadows on the white beneath' (Wright 1977 p.3). These lines also work to present the essence of Wright's life and works by talking about all the major elements that played a role in his life, from light and freedom to materials and form. Further, the hillside scape has been talked about multiple times in the book, but this specific incident provides an in-depth understanding of the working of Wright's mind. He talks about how his Uncle John walks in a perfectly straight line, yet a young Frank and his free mind wander all around the field back and forth. (Wright 1977).

Regardless of whether or not his mother's prenatal wishes for his career as an architect existed, she did definitely have an impact on his aesthetic sense. "If mother picked flowers, she would take the stems long, or the branches, and would arrange them not, as was the mode, in variegated bunches, but freely and separately-never too many together. And she always loved best a glass vase for them showing the stems in water" (Wright 1977 p.15). Though he does not admit it directly, his father too had some positive influence on his approach towards life. Speaking about himself in the third person, Wright says in his autobiography, "Father sometimes played the piano far into the night, and much of Beethoven and Bach the boy learned by heart as he lay listening...but always there was some meaning. Father taught him to see a symphony as an edifice-of sound!" (Wright 1977 p.13). The young boy observed and learned. With the claim that the purpose of becoming an architect had been ingrained in him before birth through the wishes of his mother, Wright extensively talks about the role of nature in the development of his philosophy. An upbringing on the farms gave him enough time to appreciate the natural world. He sought geometric shapes in nature and rhythm in even the mundane tasks. He mentions in his autobiography that he naturally had keen observation skills- that he was "gifted" at reading nature. "As a listening ear, a seeing eye, and a sensitive touch had been given naturally to him, his spirit was now becoming familiar with this marvelous book-of-books, experience, the only known reading-The Book of Creation. (Wright 1977, p. 26) This gift of sensory receptiveness went on to construct the young boy into Frank Lloyd Wright, the legendary architect.

Wright refers to himself in third person for his entire childhood and early youth. This could be, Ingrid Steffenson argues, to imbibe upon himself greatness since birth. It singularizes the child and talks about everything in his respect, in order to imply that the child was different. She says, 'Like his buildings, his book is constructed not in a linear fashion, but "breaks the box" and often jumps around from subject to subject, place to place, musing to musing' (Steffensen 2009 p.259). Steffensen goes on to argue that the employment of the third 
person pronoun creates a prophetic tone around the boy who would grow up to become an architect. (Steffensen 2009 p.259).

The third person narration goes on in the autobiography from the beginning until he leaves the University of Wisconsin. He dropped out before completing two years of study and remained against the conventional means of education until the end of his life. He believed more in experiential learning and valued the observations of the individual and his creativity over all other things. When Wright was offered a four-year scholarship and the following post to study the beaux-arts in Rome and travel in Europe, he rejected the proposition. When his contemporaries competed for every job other than residences, Wright happily built houses. He designed residential spaces for almost two-thirds of his professional years (Lubow 2009).

Andrew Saint, in his chapter titled 'The Architect as Hero and Genius', describes how Wright's career brings forward an era of individualism in architecture history while also directly contradicting the key influences impacting the profession in Wright's life. In his life he worked with, and preached, an extremely individualistic ideology, but also witnessed and appreciated how individuality never sufficed to get the job completed. For each project, even people from field deemed non creative, such as engineers and financial experts and legal advisors and material suppliers were required. Each task, when interlocked and done simultaneously, provided a complete building as an outcome; however, Wright, at almost every occasion possible, took the deserved- and often more than deserved-credit as the leader and the creator. His early job as an assistant at Adler and Sullivan provided him with experience of the employed him with a good grasp of the models of working in the field of architecture. $\mathrm{He}$ also had the opportunity to get well-versed with the fusion of all fields. Being a part of the building of various high-rise structures very early in his career and having faced the chaotic and pushing way of life, he decided to step away from the scape of what was called "contemporary" architecture. He desired to create art in his buildings and was completely captivated by the thought of it (Saint, 1983, p. 14-15). For a majority of his professional career he preferred designing residences. "Wright devoted himself primarily to private residences...low-slung, earth-hugging buildings with strong horizontal lines and open circulation through the public rooms, they were stripped clean of unnecessary decoration and used machine-made components" (Lubow, 2009 par.6). Throughout his career, he would often get so carried away in the 'art' aspect of his buildings that clients were forced to suffer. His works were often known to give physical discomfort to the inhabitants. Many of his houses were extremely cold, sometimes to such an extent that young couples would worry about how their unborn babies would be affected by the low temperature. His Johnson Administration Building had the problem of a falling glass, the ceiling of the Greek Orthodox Church in Wauwatosa, Wisconsin, collapsed, and many of his buildings had the problem of a leaking roof. Roowan Moore, in a 2017 article in The Guardian, claims that to letters of complaint from dissatisfied clients, the response would be that they would get "the most perfect thing of its kind in the world - a domestic symphony, true, vital, comfortable" that would work to assert them "to subsequent generations as the lover of the good! The true! The beautiful!" Similar criticisms could sometimes be found of his furniture, such as his own complaint of having bruised shins due to sitting on a chair he designed. Wright argued that all these discomforts were a small price that clients had to pay for living in a work of art (Riley 1998).

Every piece of Wright's work is art; each unquestionably dipped in greatness. Structures such as the Fallingwater and the Guggenheim Museum undoubtedly call for respect and appreciation for their author. However, his biographies and autobiographies present to the reader an image of him that is hard to admire. In the article published just days before Wright's $150^{\text {th }}$ birth anniversary, Moore says, "...nor that he was a hypocrite who preached democracy and freedom but flirted with tyrants such as Mussolini and Stalin. He was all these things..." (Moore 2017 par 3). Moore also claims that for Wright and his "selfmythologizing", "client-exploiting" contemporaries Le Corbusier and Mies van der Rohe, the best works were "so stupendous, so world-changing" that somehow everything else could be overlooked (Moore 2017).

In the process of painting a comprehensive picture of Frank Lloyd Wright, it is also important to evaluate how society and popular culture affected his image. Andrew Saint, in his book titled The Image of an Architect, argues that it was this individualistic and ambitious ideology that led him to be the inspiration behind Howard Roark, the idiosyncratic protagonist of Ayn Rand's novel, The Fountainhead (Saint 1983). Though his status as the centre of attention was reinforced by The Fountainhead, in 1970, Wright also became the first and only architect to have a song centre around him, when Simon and Garfunkel released "So Long, Frank Lloyd Wright" from their album titled Bridge over Troubled Water (Hines 1995 pg.468). His story was so inspirational and influential that it was showcased by the Civic Opera production of Shining Brow in Madison, Wisconsin. Due to this Wright received a lot of attention and became increasingly popular as an architect. These opera performances conveyed messages and themes that resonated with his personality. Hines states, 'One observer characterized the music and the production as being "melodically modernist," which could serve as a characterization of much of Wright's architecture.' (Hines 1995 pg.468). Such events that took place increased the popularity of Wrights work and these texts provided enough substance to polish his image as America's greatest architect.

\section{CONCLUSION}

Though the autobiography can be classified as misleading at times, the biographies can also be stated as biased. Academic essays play a major role in presenting a somewhat balanced analysis. Therefore, the image of the architect is constructed only after a parallel and thorough understanding of the various texts by multiple authors, presenting the multiple sides of his personality, his work and his mind.

\section{REFERENCES}

[1] Gill, B. 1987. Many Masks: A Life of Frank Lloyd Wright. London: Heinemann

[2] Hines,TS. 1995. The Search for Frank Lloyd Wright, History, Biography, Autobiography[online]. Available from: http://www.jstor.org/stable/991088 [Accessed 5 January 2020] 
[3] Lubow, A. 2009. The Triumph of Frank Lloyd Wright [online] . Available from:https://www.smithsonianmag.com/history/the-triumph-of-frank-lloydwright-132535844/[Accessed 8 January 2020]

[4] Moore, R. 2017. Frank Lloyd Wright: fantasist or genius? [online]. Available from:https://www.theguardian.com/artanddesign/2017/may/21/frank-lloydwright-fantasist-or-genius-exhibition-moma-new-york [Accessed 1 January 2020]

[5] Riley, CA. 1998. The Saints of Modern Art [online]. Available from:https://books.google.co.in/books?id=tTk5LqMgnZAC\&lpg=PA165\&o ts=EqhjxQKtZu\&dq=light $\% 20$ blanket $\% 20$ of $\% 20$ snow $\% 20$ fresh $\% 20$ fallen $\% 20$ over\%20frank\%201loyd $\% 20$ wright \&pg=PA165\#v=onepage \&q=light $\%$ 20blanket $\% 20$ of $\% 20$ snow $\% 20$ fresh $\% 20$ fallen $\% 20$ over\%20frank\%20lloyd $\% 20$ wright \&f=false [Accessed 2 January 2020]

[6] Saint, A. 1983.The Architect as Hero and Genius [online]. Available from: https://www.jstor.org/stable/j.ctt1ww3w0s?turn_away=true [Accessed 7 January 2020]
[7] Steffensen, I. 2009. Frank Lloyd Wright and the "Gift" of Genius [online]. Available from: https://onlinelibrary.wiley.com/doi/pdf/10.1111/j.1542734X.2009.00715.x [Accessed 2 January2020]

[8] Wright, FL. 1977. An Autobiography [online]. (rev. ed.) Available from: https://books.google.co.in/books?id=S8zlZcJjNEMC \&printsec=frontcover $\&$ source=gbs_ge_summary_r\&cad $=0 \# \mathrm{v}=$ onepage $\& \mathrm{q} \& \mathrm{f}=$ false [Accessed 5 January 2020]

\section{AUTHORS}

First Author - Maryam Siddiqui, Faculty of Architecture and Ekistics, Jamia Millia Islamia, maryam_rabila@yahoo.com Second Author - Chaitali Ahuja, University of Toronto, chaitaliahuja1999@gmail.com 